\title{
Covered interest arbitrage opportunities in the South African foreign exchange market
}

\author{
C. de J. Correia
}

Department of Accounting, University of Cape Town, Private Bag, Rondebosch, Cape Town, 7700 Republic of South Africa

\author{
R.F. Knight
}

Graduate School of Business, University of Cape Town, Private Bag, Rondebosch, Cape Town, 7700 Republic of South Africa

\begin{abstract}
The Interest Parity Theory states that in an efficient market, any interest differential between local and foreign sources of finance will be offset by the forward premium/discount. Therefore, opportunities to engage in profitable Covered Interest Arbitrage transactions will be eliminated quickly. The fall in the Rand/Dollar exchange rate resulted in many South African companies reporting substantial foreign exchange losses on offshore loans. Companies were attracted to foreign sources of finance because of lower foreign interest rates. The authors conclude, on the basis of empirical tests, that the forward Rand/Dollar exchange rate followed its interest parity value very closely over the period August 1983 - August 1985. Opportunities to engage in riskfree arbitrage activities were offset by related transaction costs. The South African foreign exchange market is efficient to the extent that risk-free profit opportunities did not exist for the period under review and therefore there was no benefit, after adjusting for risk, for South African management to borrow from offshore sources of finance.
\end{abstract}

\begin{abstract}
Die Rentepariteitsteorie stel dat renteverskille tussen plaaslike en buitelandse finansieringsbronne in 'n doeltreffende mark die termyndekkingspremie/-korting sal teenwerk. As gevolg hiervan sal geleenthede onm in winsgewende rente-arbitrasietransaksies deel te neem gou geëlimineer word. Heelwat Suid-Afrikaanse maatskappye het as gevolg van die afname in die Rand/Dollar-wisselkoers wesenlike wisselkoersverliese gely op buitelandse lenings. Maatskappye het buitelandse finansieringsbronne aantreklik gevind as gevolg van laer buitelandse rentekoerse. Die outeurs het op grond van empiriese toetse tot die gevolgtrekking gekom dat termyndekking op die Rand/Dollar-wisselkoers vir die periode Augustus 1983 tot Augustus 1985 sy rentepariteitswaarde baie nou gevolg het. Geleenthede om in risikovrye arbitrasie-aktiwiteite deel te neem is teengewerk deur verwante transaksiekostes. Die Suid-Afrikaanse buitelandse valutamark was doeltreffend vir die periode onder bespreking aangesien geen risikovrye winsgeleenthede vir daardie periode bestaan het nie. Dit volg dat nadat risiko-aanpassings gemaak is, daar geen voordeel vir Suid-Afrikaanse bestuur bestaan het om buitelandse finansieringsbronne te gebruik nie.
\end{abstract}

\section{Introduction}

In this paper the efficiency of the South African foreign exchange market is tested regarding quick elimination of risk-free profit opportunities. Deviations from interest parity imply that opportunities exist to undertake profitable covered interest arbitrage transactions. Interest parity and covered interest arbitrage have been analysed by, amongst others, Aliber (1973), Barr \& Kantor (1984), Frenkel \& Levich $(1975,1977)$ and Levich (1979). Levich analysed interest parity in relation to market efficiency. Interest parity deviations will not imply that the foreign exchange market is inefficient if apparent covered interest arbitrage profit opportunities are not sufficient to offset related transaction costs. Levich (1979: 39) submitted that, 'A fundamental property of an efficient market is that risk free profit opportunities do not exist'. He found, in empirical tests of the major currencies, that most risk-free profit opportunities were quickly eliminated. In this paper a study of interest parity in the South African foreign exchange market is reported.

The advent of the Interim report of the Commission of Inquiry into the Monetary System and Monetary Policy in South Africa (hereafter referred to as the 'Commission report') in 1979, heralded the beginning of a period of stated Reserve Bank policy of moving towards market-related exchange rates. The Reserve Bank reforms culminated in the decision on 15 February
1983 to lift the restrictions on non-residents thereby effectively abolishing South Africa's dual exchange rate system. In August 1983, the Reserve Bank further attempted to expand the foreign exchange market by allowing the mining houses to have their gold sales proceeds paid in dollars. In September 1985 with the declaration of the foreign debt moratorium and the introduction of restrictions on non-residents, the Financial Rand was reintroduced. Other reforms were reversed and further direct controls were imposed.

The period August 1983 - August 1985 was studied (based on weekly observations), where technical imperfections were minimal (particularly in the spot market) and the movement in the Rand/Dollar rate was dramatic. The objectives of this study may be stated as follows:

1. To evaluate whether risk-free arbitrage profit opportunities existed during the period August 1983 August 1985, and

2. To provide empirical evidence on the efficiency of the South African foreign exchange market during the above period.

Developments in the South African forward exchange market since 1979 are reviewed, in order to evaluate whether the technical state of the market was conducive to allow the efficient operation of market forces. The terms, covered interest arbitrage and interest rate parity are then defined and regression analysis is employed to test the relationship between the quoted forward dollar 
premium and its interest parity value. The interest parity equation is plotted against the quoted forward dollar premium. Deviations from interest parity are analysed and transaction costs are taken into account to conclude on arbitrage opportunities during the period under review. The only countries studied are South Africa and the U.S.A.

The authors found that deviations from interest parity did occur during the period August 1983 - August 1985, but these apparent risk-free arbitrage profit opportunities were not sufficient to offset relevant transaction costs. Therefore, the hypothesis that the South African foreign exchange market has met a basic requirement for market efficiency, that is, risk-free profit opportunities should be quickly eliminated, cannot be rejected as a result of this study.

\section{The South African forward exchange market}

Prior to the implementation of the Commission recommendations, the South African Reserve Bank set the cost of forward cover at a fixed commission rate of $1 \%$ per annum. This applied to both purchases and sales of forward foreign currency. As the Commission noted, the forward rates were not determined by the forces of supply and demand. This policy resulted in two prices instead of one being quoted for the same commodity. Forward dollars were sold to importers at one price and bought from exporters at another price. In a developed forward exchange market, apart from a narrow bid-ask spread, there is only one price for forward dollars at any point.

The Reserve Bank's forward cover policy had an important effect on the movement of funds in and out of South Africa. If local interest rates exceeded foreign interest rates by more than $1 \%$, there existed an incentive for South African importers to obtain finance from foreign sources. Once this occurred, however, there was pressure on the the Reserve Bank not to increase the cost of forward cover or reduce local interest rates as this would have an adverse effect on the Reserve Bank's foreign exchange reserves.

The policy of setting the cost of forward cover at $1 \%$ per annum encouraged public corporations to raise funds in hard currencies like the Deutche Mark and the Swiss Franc. Lower interest rates were matched by the appreciation in the value of these currencies. This increased the foreign loan liabilities in terms of local currency. The public corporations bought these currencies forward at a cost of only $1 \%$ per annum. This resulted in the Reserve Bank and the Treasury incurring substantial foreign exchange losses on the forward account. The Reserve Bank then introduced a ruling that it would only provide forward cover for the Rand/Dollar rate.

The Interim report of the Commission of Inquiry recommended a policy of setting the forward premium/ discount on the basis of interest differentials. This would reflect an efficient and competitive market as covered interest arbitrage would ensure this relationship in a free market.
Owing to the material foreign exchange losses incurred on the forward account, the Reserve Bank set a programme to disengage from the forward exchange market by September 1986. The Reserve Bank introduced a spot-swap system to link the forward market to the spot market (Gidlow, 1986). Owing to economic and political developments disengagement from the forward market was not possible.

\section{Covered interest arbitrage}

Covered interest arbitrage constitutes a swap transaction where parties move funds across boundaries to take advantage of differential interest rates. This arbitrage is risk free (apart from political risk) in that if a firm borrows dollars offshore to deposit in South African securities, the firm will simultaneously buy dollars forward.

If the interest rate differential between South Africa and the U.S.A. is substantially different to the forward dollar premium/discount, an incentive would exist to enter into a profitable arbitrage transaction. In an efficient market, risk-free arbitrage profit opportunities should be quickly eliminated.

Starting from first principles, we would expect the following equation to be satisfied in an efficient market:

$x(1+i)-x=x\left(1+i^{f}\right) S / F-x$

where $x=$ initial amount stated in Rand; $i=$ domestic interest rate; $i^{f}=$ foreign interest rate; $S=$ spot exchange rate (indirect quotation); and $F=$ forward exchange rate (indirect quotation)

If Equation (1) is not satisfied, opportunities will exist to enter into profitable covered interest arbitrage transactions, subject to the condition that the inequality is sufficient to offset any related transaction costs. This situation is depicted in Figure 1.

\section{Interest rate parity theorem (IRPT)}

The theory of interest rate parity states that for securities of similar risk, the quoted forward premium/discount should be equal to the interest differential divided by one plus the interest rate. The IRPT is a restatement of Equation (1) and is mathematically denoted as:

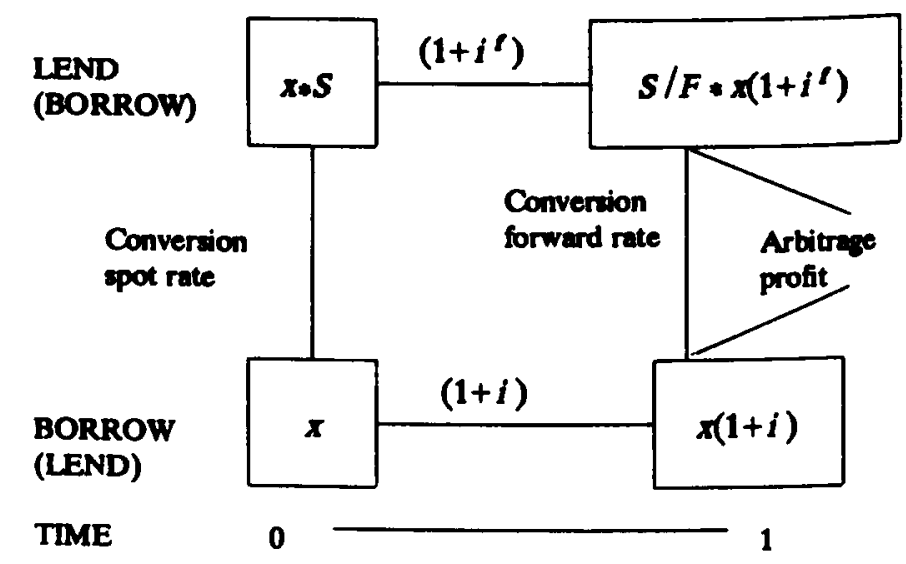

Figure 1 Covered interest arbitrage flow 
$\frac{S-F}{S}=\frac{i-i^{f}}{1+i}$

where $S=$ spot exchange rate (indirect quotation); $F=$ forward exchange rate (indirect quotation); $i=$ domestic interest rate; and $i^{f}=$ foreign interest rate

Let:

$Q=(S-F) / S$

$I=\left(i-i^{f}\right) /(1+i)$

\section{Forward dollar premium}

If $Q<I$, then the interest differential is not fully offset by the forward dollar premium. The effect of this inequality is to encourage capital flows into South Africa. The demand for spot rands will increase, thereby increasing $S$ in the IRPT equation. At the same time the demand for forward dollars increases, and $F$ falls. This means that the forward premium, $Q$, will increase and taking together the effects on relative interest rates owing to the movement of funds, the interest parity equation will be satisfied.

If $Q>I$, then the quoted forward dollar premium more than offsets the interest differential. This will have the effect of encouraging capital outflows from South Africa. The demand for spot dollars will increase while the demand for forward dollars will decline. Therefore the spot rate, $S$ will fall and the forward rate, $F$, will rise, thereby reducing $Q$ to a level that reinstates interest parity. The interest parity equation and covered interest arbitrage opportunities are graphically depicted in Figure 2.

All observations on the line represent situations where the interest parity condition is satisfied, i.e. where the forward dollar premium/discount equals the interest differential divided by one plus the domestic interest rate. Observation $A$ represents a situation where the quoted forward dollar premium exceeds its interest parity value(i.e. $Q>I$ ). In a perfect market this would result in capital outflows until interest parity is restored.

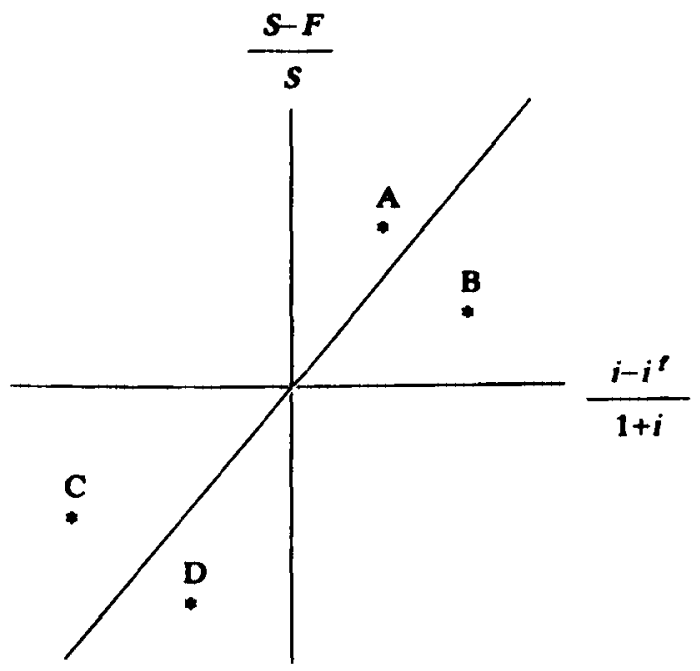

Flgure 2 Interest parity theory
Observation B represents a situation where the quoted forward dollar premium is less than its interest parity value (i.e. $Q<I$ ). Again, in a perfect world this would result in capital inflows to South Africa to take advantage of the covered interest arbitrage opportunity.

This paper focuses attention upon situations where the forward dollar premium deviates from its interest parity value. This is due to the fact that for the period under review the forward dollar was consistently at a premium to the spot rate. Observations $C$ and $D$ reflect situations where the forward dollar discount deviates from its interest parity value. Observation D will result in capital inflows as the forward discount exceeds its interest parity value. As the quoted forward discount is less than its interest parity value in observation $C$, this will result in capital outflows.

Covered interest arbitrage will not necessarily restore interest parity owing to the transaction costs involved in the buying and selling operations. Therefore, market efficiency requires that the interest parity equation is satisfied to the extent that the observations lie within the transaction cost boundaries around the IRPT line.

\section{Empirical study}

A regression was run on Micro TSP (version 4.1) to test the interest parity equation for the period August 1983 August 1985. Data were obtained from Standard Bank. The data consist of 102 weekly observations of three monthly South African and New York Bankers' Acceptance rates, weekly spot Rand/Dollar rates and weekly three-month quoted forward dollar premiums. The Bankers' Acceptance rates are before any bank commission and stamp duty. As the data are stated in annualized terms it is necessary to transform the data by dividing by four. Transformation is necessary otherwise the relationships between the variables will be misspecified. The tests require that securities of similar risk be compared, therefore Bankers' Acceptance rates were selected to test for interest parity. It will be noted that there are differences in terms of political risk but as the rates are of a short-term nature, it is assumed that the effects thereof are minimal.

\section{Regression equation}

The following regression equation was specified:

$Q=a+b I+\mathrm{e}_{t}$

where $Q=(S-F) / S ; I=\left(i-i^{f}\right) /(1+i) ;$ and $\mathrm{e}_{1}=$ white noise term

$F$ and $S$ are stated in terms of indirect quotations.

\section{Rosults}

The results of the regression equation are presented in Table 1 . The Interest Parity Theory requires that the beta coefficient is close to one. The regression results in a beta coefficient of 0,96 which is statistically significant at the $1 \%$ level of significance. The $R^{2}$ is $96,3 \%$ indicating a high degree of correlation between the quoted Dollar premium $(Q)$ and its interest parity value 
(I). To correct for auto-correlation, the data have been transformed using the Cochrane-Ocutt method. The results of the revised equation are also presented in Table 1 . The beta coefficient is 0,92 which is statistically significant at the $1 \%$ level of significance and the $R^{2}$ is $97,5 \%$. The Durbin-Watson (DW) statistic is now 2,10 indicating the correction for serial correlation.

The forward quoted dollar premium $(Q)$ is plotted against its interest parity value $(I)$ in Figure 3.

It will be noted from Figure 3 that the quoted forward dollar premium has tended to follow the interest parity equation very closely. The question is whether during

Table 1 Regression equation results $Q=a+b I+e_{t}(t$ statistics in parentheses)

\begin{tabular}{lcccccc}
\hline$a$ & $t_{a}$ & $b$ & $t_{b}$ & $R^{2}$ & $D W$ & $F$ \\
\hline $1.0,0008$ & $(1,65)$ & 0,96 & $(51,02)$ & $96,3 \%$ & 0,83 & 2603 \\
$2.0,0016$ & $(1,62)$ & 0,92 & $(23,57)$ & $97,5 \%$ & 2,10 & 1910 \\
\hline
\end{tabular}

1 = Ordinary least squares regression equation

$2=$ Cochrane-Ocutt transformation

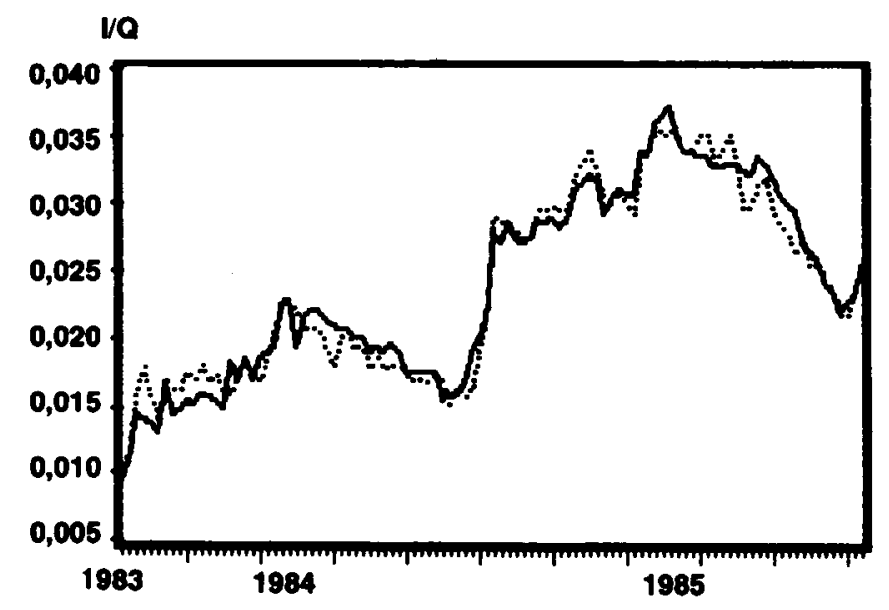

- 1

Figure 3 The relationship between interest parity and the quoted dollar premium (Aug 1983 - Aug 1985).

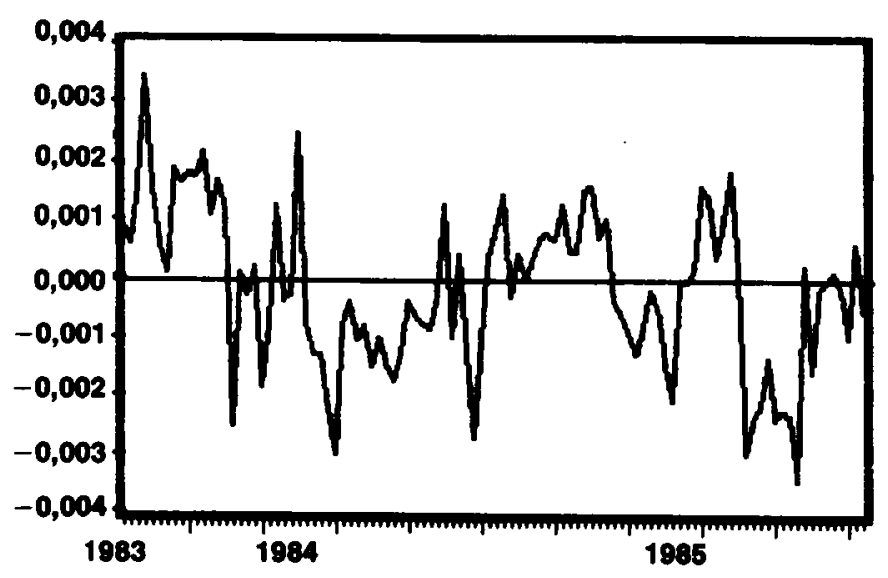

Figure 4 Deviations from interest parity (Aug 1983 - Aug 1985) this period any risk-free arbitrage opportunities existed? The following equation was formulated to test for the existence of arbitrage opportunities:

$D=Q-I$

where $D=$ deviation from interest parity.

Deviations from interest parity are plotted in Figure 4.

The summary statistics for the deviations depicted in Figure 4 are presented in Table 2 . It will be noted that deviations from interest parity did not exceed 0,34 percentage points. The mean deviation is very close to zero and two thirds of the deviations lie within approximately 0,13 percentage points of the mean.

Table 2 Summary statistics

\begin{tabular}{lccl}
\hline Mean & $S D$ & Max. & Min. \\
\hline$-0,000186$ & 0,0013659 & 0,0034 & $-0,0034$ \\
\hline
\end{tabular}

To determine the covered interest arbitrage opportunity spread, it is necessary to translate the interest parity percentage deviations into exchange rate points. This is achieved by multiplying the deviations by the spot rate at each point in time. Deviations in terms of exchange rate points are presented in Figure 5.

The summary statistics of interest parity deviations in terms of exchange rate points are presented in Table 3. The mean is very close to zero. The mean deviation is less than one exchange rate point. Two thirds of the deviations are within 10 points of the mean. The maximum and minimum deviations are 31 and 25 points respectively.

Before any conclusions can be made whether arbitrage opportunities existed, it is important to include transaction costs in the analysis.

\section{Transaction costs}

Transaction costs may be divided into two components:

1 . The bid-ask spread in buying and selling foreign currency, and,

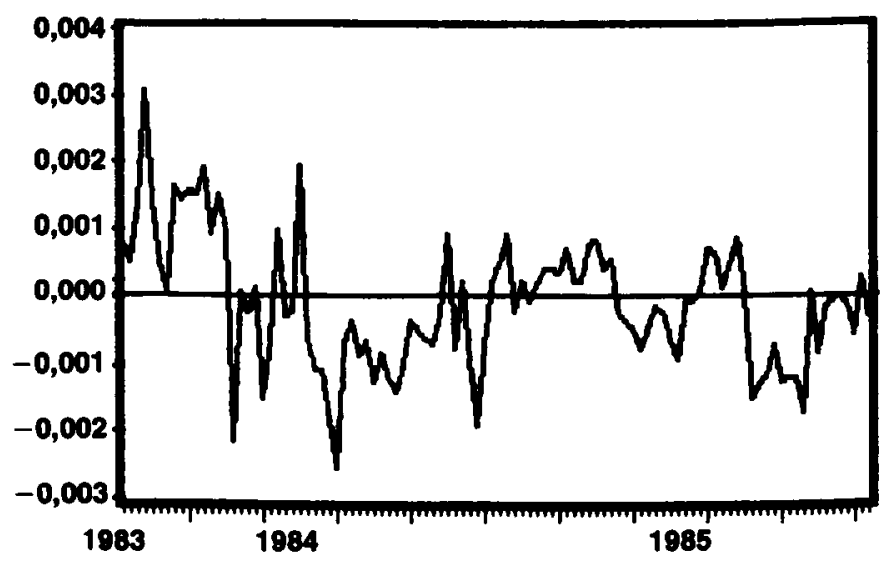

Figure 5 Covered interest arbitrage opportunity spreads (Aug 1983 - Aug 1985). 
Table 3 Summary statistics

\begin{tabular}{lccc}
\hline Mean & $S D$ & Max. & Min. \\
\hline 0,00008 & 0,00097 & 0,00310 & $-0,00250$ \\
\hline
\end{tabular}

2. The transaction costs involved in dealing in Bankers' Acceptances.

A swap transaction involves the buying and selling of foreign currency. The bid-ask spread represents the bankers' profit for its brokerage function. Rand/Dollar bid-ask spreads at the retail level (for smaller amounts) are presented in Table $\mathbf{4}$ for specified dates.

The spot market has reflected a spread of 100 points whereas the spread on the forward market is approximately 120 points. The magnitudes of these spreads will prevent firms from being able to take advantage of deviations from interest parity. In the Interbank market the bid-ask rates reflect significantly reduced margins and the average spread is approximately 10 points in the spot market. The bid-ask spread is wider in the forward market. A swap transaction involves a spot and a forward transaction. If the spread in the forward market is 12 points, then the average spread for an arbitrageur for both legs of the swap transaction would be 11 points.

The transaction costs in bankers' acceptances include bank commission and stamp duty. The acceptance commission is approximately $1,5 \%$ per annum of the nominal value and the stamp duty amounts to 5 cents for every R100 (0,05\%). Demsetz (1968), in a study of the U.S. foreign exchange market, found that transaction costs in buying and selling securities were on average 2,5 times the costs of transacting in the foreign exchange market. Frenkel \& Levich (1977) found that transaction costs increased significantly during periods of volatility in the foreign exchange market. Even if the ratio of transaction costs in the security markets to costs in the foreign exchange market was significantly below 2,5 , this would still imply that total transaction costs were sufficient to offset any arbitrage profit opportunity during the period under review. If the combined bid-ask spread facing an'arbitrageur is 11 points in the spot and forward markets, then the ratio of security transaction

Table 4 Bid-ask spreads in spot and forward rates

\begin{tabular}{|c|c|c|c|c|c|c|}
\hline \multirow[b]{2}{*}{ Date } & \multicolumn{3}{|c|}{ Spot } & \multicolumn{3}{|c|}{ Forward } \\
\hline & Bid & Ask & Spread & Bid & Ask & Spread \\
\hline $30 / 05 / 84$ & 0,7690 & 0,7790 & $100 \mathrm{pts}$ & 0,7518 & 0,7672 & 154pts \\
\hline $30 / 08 / 84$ & 0,6365 & 0,6465 & $100 \mathrm{pts}$ & 0,6193 & 0,6305 & $112 p t s$ \\
\hline $30 / 11 / 84$ & 0,5315 & 0.5415 & 100 pts & 0,5149 & 0,5272 & 123pts \\
\hline $28 / 02 / 85$ & 0,4985 & 0,5085 & $100 \mathrm{pts}$ & 0,4806 & 0,4926 & $120 \mathrm{pts}$ \\
\hline $30 / 05 / 85$ & 0,4970 & 0,5070 & $100 p t s$ & 0,4827 & 0,4947 & $120 \mathrm{pts}$ \\
\hline 27/08/85 & 0,3700 & 0,3800 & $100 \mathrm{pts}$ & 0,3670 & 0,3790 & 120 pts \\
\hline
\end{tabular}

Rand Bid rates/Rand Ask rates stated in U.S. Dollar terms. costs to foreign exchange transaction costs need only be 1,8 to offset any covered interest arbitrage opportunity. It is reasonable to conclude therefore, that transaction costs exceeded the maximum arbitrage profit opportunity of 31 points over the period under review. Two thirds of the deviations from interest parity did not exceed 10 points, which is less than the costs on just the foreign exchange side of any arbitrage transaction.

\section{Conclusion}

Apparent risk-free arbitrage profit opportunities did exist over the period August 1983 - August 1985 but these were offset by related transaction costs. The South African Reserve Bank controls the forward exchange market. It has however simulated an efficient market by setting the quoted forward dollar premium very close to the interest parity equation. This is in contrast to the period prior to the Commission of Inquiry Interim report when the forward dollar premium/discount was set at arbitrary levels.

The study was not able to reject the hypothesis that the South African foreign exchange market is efficient to the extent that covered interest arbitrage opportunities are quickly eliminated. This conclusion has implications for the decision to obtain offshore finance. South African companies were attracted to foreign sources of finance due to lower foreign interest rates. The results given in this paper presents evidence that the advantage of lower foreign interest rates was offset by the cost of forward cover (the forward Dollar premium) and therefore there was no benefit, after adjusting for risk, for South African management to borrow from offshore sources of finance.

\section{References}

Aliber, Robert Z. 1973. The Interest Rate Parity Theorem: A Reinterpretation. J. Pol. Econ. vol. 81, 1451-1459.

Allen, William A. 1977. Note on Uncertainty, Transaction

Costs and Interest Parity. J. Mon. Econ., vol. 3, 367-373.

Barr, G.D.I. \& Kantor, B.S. 1984. Interest rates, the Exchange Rate and Money Supply in South Africa. Invest. Anal. J., no.23.

Demsetz, Harold. 1968. The Cost of Transacting. Quart. J. Econ., vol. 82, 33-53.

Exchange Rates in South Africa. Interim report of the Commission of Inquiry into the Monetary System and Monetary Policy in South Africa. RP112/1978.

Frenkel, Jacob A. \& Levich, Richard M. 1975. Covered Interest Arbitrage: Unexploited Profits? J. Pol. Econ., vol. 83, 325-338.

Frenkel, Jacob A. \& Levich, Richard M. 1977. Transaction Costs and Interest Arbitrage: Tranquil versus Turbulent Periods. J. Pol. Econ., vol. 85, 1209-1226.

Gidlow, R.M. Intervention in the Forward Market by the Reserve Bank under the Spot-Swap system. S. Afr. J. Econ., vol.54, 250-262.

Levich, Richard M. 1979. The International Money Market: 
An assessment of Forecasting Techniques and Market Efficiency. In Contemporary Studies in Economic and Financial Analysis, vol.22. Edited by E.I.Altman and I. Walter. Greenwich, Connecticut. Jai Press Inc.
The Monetary System and Monetary Policy in South Africa Final(and Interim) report of the Commission of Inquiry into the Monetary System and Monetary Policy in South Africa 1984. RP 70/1984. 